\title{
HIPONIMI DAN POLISEMI BAHASA INDONESIA DAN BAHASA SUNDA
}

\author{
Irman Nurhapitudin dan Fakri Hamdani \\ Dosen Bahasa dan Sastra Inggris Fakultas Adab dan Humaniora \\ UIN Sunan Gunung Djati Bandung \\ irmannd@gmail.com
}

\begin{abstract}
Kesulitan atau kekeliruan dalam menafsirkan makna dari dua jenis kosa kata dalam bahasa Indonesia dan bahasa Sunda sangat jelas terlihat jika pentuur keduanya melakukan interaksi dengan penutur lainnya. Untuk membuktikan keberadaannya, maka diperlukan penelitian bahasa yang bersangkutan dengan kajian leksikal dan semantik terhadap bahasa Indonesia dan bahasa Sunda dilihat dari adanya persamaan kosa kata tertentu pada keduanya. Dari hasil pengamatan sementara terhadap para dwibahasawan yang berbahasa ibu bahasa Sunda di masyarakat Kampung Jati, Kec. Tarogong Kaler , Kab.Garut, diketahui bahwa mereka sering menggunakan kosa kata yang sama baik dalam bahasa Indonesia maupun bahasa Sunda dalam percakapan sehari-hari. Secara leksikal, kosa kata polisemi bahasa Indonesia lebih banyak dibandingkan dengan bahasa Sunda. Hal ini disebabkan karena faktor kedudukan bahasa Indonesia sebagai bahasa nasional dengan cakupan penutur yang lebih banyak dari bahasa Sunda. Berdasarkan data, bahasa Sunda memiliki empat buah polisemi, yakni: kata amis, kata burung, kata jarah , kata lini,.Adanya relasi makna antara kosa kata bahasa Indonesia dan bahasa Sunda yang ditunjukkan dengan banyaknya sumber data kosa kata berhiponimi dan polisemi.
\end{abstract}

Kata Kunci: hiponim, polisemi, bahasa indonesia, bahasa sunda

\section{PENDAHULUAN}

Bahasa Indonesia merupakan bahasa yang berkedudukan sebagai bahasa persatuan. Karenanya, setiap masyarakat Indonesia yang berada di daerah-daerah tetap menggunakannya sebagai bahasa yang berada di barisan paling depan. Artinya, walaupun mereka menggunakan bahasa daerah sebagai bahasa seharihari, mereka tetap memegang teguh nilai-nilai yang terdapat dalam bahasa Indonesia. Bahkan, sebagian dari bahasa daerah mereka pun mengambil beberapa kosa kata serapan dari bahasa Indonesia.
Masyarakat pengguna bahasa di Indonesia adalah dwibahasawan dan bahasa Indonesia merupakan bahasa bahasa kedua bagi sebagian masyarakat Indonesia. Fenomena ini sejalan dengan pemikiran William Mackey yang menyatakan bahwa jika bahasa merupakan milik suatu kelompok, maka bilingulisme merupakan milik penuturnya (1968:554). Masyarakat dwibahasa berkomunikasi dengan menggunakan pilihan-pilihan kata yang sesuai dengan konteks bahasanya. Umumnya, hal ini dilakukan untuk menyampaikan keinginan pembicaraan mereka. Sangat wajar 
bila pada masyarakat dwibahasa di Indonesia terdapat beberapa penempatan yang tidak sesuai dengan apa yang mereka inginkan. Hal ini disebabkan adanya kebutuhan akan bahasa Indonesia sebagai bahasa nasional dan pemertahanan bahasa daerah, sehingga para dwibahasawan akan memilih sebuah kata dari dua acuan yang berbeda.

Dalam kehidupan sehari-hari masyarakat Sunda, pemakaian bahasa Indonesia dan bahasa Sunda saling mengisi satu sama lainnya. Keduanya digunakan dalam kontekskonteks situasi tertentu untuk mencapai sebuah pemahaman bahasa yang dapat diterima oleh penuturnya. Untuk mewujudkan pemahaman tersebut, penutur dwibahasa ini berusaha mencari kosa kata yang sesuai maknanya baik dalam bahasa Indonesia maupun bahasa Sunda. Akan tetapi, para pengguna dua bahasa ini seringkali mengalami kesulitan dalam memilih kosa kata tertentu. Fenomena ini disebabkan oleh adanya beberapa kesamaan bentuk dalam kedua bahasa dengan makna yang berbeda. Berdasarkan teori Ferdinand de Saussure yang menyatakan bahwa tanda dan nilai dalam sebuah makna dapat dibedakan, maka perbedaan makna dari kosa kata ini dapat dijelaskan lebih rinci kedudukannya. Contohnya, kata mouton dalam bahasa Perancis mungkin sama artinya dengan kata sheep dalam bahasa Inggris, tapi mempunyai nilai yang berbeda. Bahasa Inggris tidak bisa menggunakan kata sheep untuk menunjukkan 'daging kambing yang siap disajikan', akan tetapi padanannya ada pada kata mutton. Sementara itu, dalam bahasa Perancis, kata mutton mempunyai dua buah arti, yaitu sebagai 'daging kambing yang siap disajikan' dan 'kambing' (Saussure 1971:115-116). Saussure tidak melihat adanya perbedaan hubungan diantara konsep dan makna, akan tetapi perbedaan itu ada pada tanda-tandanya.

Kesulitan atau kekeliruan dalam menafsirkan makna dari dua jenis kosa kata dalam bahasa Indonesia dan bahasa Sunda sangat jelas terlihat jika penuur keduanya melakukan interaksi dengan penutur lainnya. Untuk membuktikan keberadaannya, maka diperlukan penelitian bahasa yang bersangkutan dengan kajian leksikal dan semantik terhadap bahasa Indonesia dan bahasa Sunda dilihat dari adanya persamaan kosa kata tertentu pada keduanya.

Dari hasil pengamatan sementara terhadap para dwibahasawan yang berbahasa ibu bahasa Sunda di masyarakat Kampung Jati, Kec. Tarogong Kaler, Kab.Garut, diketahui bahwa mereka sering menggunakan kosa kata yang sama baik dalam bahasa Indonesia maupun bahasa Sunda dalam percakapan sehari-hari. Walaupun tidak terlalu dominan, akan tetapi kosa kata tersebut hadir dalam kalimat-kalimat dengan konteks yang berbeda. Oleh karena itu, ruang lingkup penelitian ini dibatasi hanya meneliti penggunaan kosa kata yang berbentuk sama dengan makna yang berbeda dalam bahasa Indonesia dan bahasa Sunda, dengan mengacu kepada bahasa sehari-hari yang dipakai oleh masyarakat Sunda. Sebagai contoh misalnya bentuk kata "asa" bahasa Indonesia mempunyai makna 'harapan', sedangkan dalam bahasa Sunda bermakna 'seperti'.

Permasalahan makna ini secara langsung berhubungan dengan dua konteks bahasa, yakni semantik 
dan leksikon yang akan mengantarkan kita pada pemahaman mengenai hominimi dan polisemi. Pengertian ini didukung oleh pendapat Geoffrey Leech yang menyatakan bahwa konvergensi pendekatan historis dan sinkronis terhadap leksikon pada akhirnya membawa kita kepada problema yang telah lama menjadi perhatian mereka yang mempelajari semantik: bagaimana orang menarik garis antara homonimi dan polisemi (2003:278).

Persamaaan kosa kata bermakna lain dalam dua buah bahasa ini umumnya terjadi dalam masyarakat dwibahasawan atau komunitas dua bahasa ketika mereka berintaraksi. William Mackey mengemukakan bahwa Interaksi bahasa dari dwibahasawan mungkin terjadi dalam konteks bahasa yang digunakan di rumah, dalam komunitas tertentu, di sekolah, dalam komunikasi media massa dan korespondenya (1968:558). Akhirnya, ruang lingkup penelitian ini mencoba untuk meramu relasi makna di antara kosa kata hominimi dan polisemi dalam bahasa Indonesia dan bahasa Sunda.

Dari berbagai konsiderasi yang muncul dalam latar belakang penelitian di atas, penelitian ini dilakukan dengan tujuan untuk (1) mencari kehadiran kosa kata berbentuk sama dengan makna yang berbeda dalam bahasa Indonesia dan bahasa Sunda; (2) mencari relasi makna kosa kata homonimi dan polisemi dalam bahasa Indonesia dan bahasa Sunda; dan (3) mencari aspek sosial dan psikologis dari penutur bahasa Sunda ketika menempatkan kata-kata tersebut dalam kalimatkalimat bahasa Indonesia dan bahasa Sunda.

\section{Landasan Teori}

Kerangka teori penelitian ini terdiri atas beberapa teori dasar mengenai penelitian konstrastif dan kajian semantik terhadap kosa kata homonimi dan polisemi. Menurut Sudaryono, setiap kerja penelitian yang menghendaki hasil tertentu dalam setiap langkahnya selalu harus bekerja dengan cara pembandingan atau menggunakan hubungan banding itulah dapat diketahui ada tidaknya hubungan kesamaan dan perbedaan fenomena-fenomena penggunaan bahasa (1988:63). Oleh karena itu, teori yang mendasari penelitian ini meliputi makna dan relasi makna.

Istilah makna sebenarnya sudah sangat biasa kita dengar dalam kehidupan sehari-hari. Para ahli banyak memberikan pendapat yang berbeda-beda mengenai teori makna. Teori yang dianggap bisa menjawab rahasia makna adalah teori abstrak atau acuan (signification). Teori ini diungkapkan oleh Saussure dengan menyatakan bahwa makna terdiri dari dua komponen, yaitu komponen signifian atau "yang mengartikan" yang berwujud runtunan bunyi, dan komponen signifie atau "yang diartikan" yang wujudnya berupa pengertian atau konsep yang dimiliki oleh signifian. Teori ini berdasarkan pada aspek makna konseptual dan kognitif dan dibagi menjadi tiga buah komponen, yaitu bentuk bunyi atau tanda linguistic, konsep, dan acuan.

Dalam kehidupan sehari-hari, makna suatu kata tidak tidak hanya makna leksikal yang dimilikinya, tetapi menjangkau aspek yang lebih luas. Kenyataan menunjukkan bahwa banyak kata dengan bermacam ragam makna bila dihubungkan dengan kata lain. Pengertian makna sense dibedakan dari arti meaning 
dalam kajian semantik. Kata mean dapat ditafsirkan berbeda dalam beberapa kalimat seperti:

I mean to be here tomorrow ( mean $=$ bermaksud)

That cloud means thunder (mean = membawa)

$A$ red light means stop (mean=bermakna)

Kita juga bisa melihat perbandingan makna ini dalam bahasa Indonesia, seperti dalam contoh di bawah ini:

(a) Tolong belikan amplop !

(b) Beri saja dia amplop

Kata amplop pada (a) dan (b) dianggap sebagai kata A, sedangkan unsur yang bergabung dapat dianggapa B atau C. Pada (a) amplop bermakna 'pembungkus surat', sedangkan pada (b) bermakna 'uang suap'. Pada hakikatnya makna tersebut muncul sebagai akibat hubungan antarunsur (Djajasudarma, 1999:7).

Mengenai relasi makna, bahasa mengantarkan penuturnya untuk mencapai tingkat pemahaman terhadap makna. Hubungan antara sebuah kata dengan kata lainnya dapat menimbulkan sebuah relasi makna di dalamnya. Persamaan bentuk kosa kata dalam sebuah bahasa atau lebih menuntut para penutur bahasa tersebut untuk menempatkannya dalam sebuah kalimat agar dapat dimengerti oleh penutur yang lainnya. Fenomena ini akan terlihat dengan jelas ketika penutur merupakan dwibahasawan atau multibahasawan. Relasi makna yang akan dijelaskan pada penelitian ini terdiri atas homonim dan polisemi.

Kata homonimi berasal dari bahasa Yunani kuno onoma yang artinya 'nama' dan homo yang artinya 'sama;. Secara harfiah homonimi dapat diartikan sebagai 'nama sama untuk benda atau hal lain' (Chaer, 2002:93). Sementara itu Palmer menyatakan bahwa dalam homonimi bukan hanya perbedaan kata dapat menyebabkan perbedaan makna saja, akan tetapi lebih pada kasus kesamaan kata yang mempunyai makna-makna yang berbeda (1981:100).

Chaer (2002) kemudian menjelaskan bahwa hubungan antara dua buah kata yang homonim bersifat dua arah. Artinya, kalau kata bisa yang berarti 'sanggup', maka kata bisa yang berarti 'sanggup' juga homonym dengan kata bisa yang berarti 'racun ular'. Kalau kata bisa yang berarti 'racun ular' kita sebut bisa I dan kata bisa yang berarti 'sanggup' kita sebut bisa II , maka diagramnya menjadi sebagai berikut:

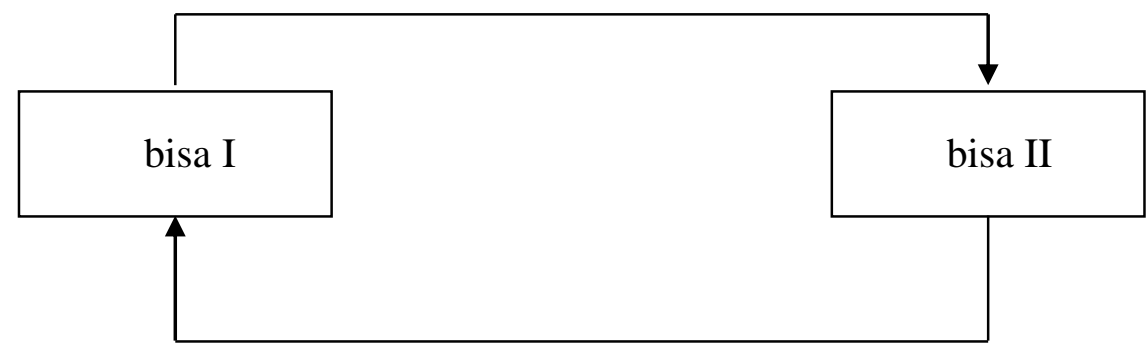

Diagram homonimi kata 'bisa' (Chaer, 2002:95). 
Bentuk-bentuk yang berhomonimi berasal dari bahasa atau dialek yang berlainan. Misalnya kata bisa yang berarti 'racun ular' berasal dari bahasa Melayu, sedangkan kata bisa yang berarti 'sanggup' berasal dari bahasa Jawa.

Kasus homonimi, sebagaian ahli bahasa menyebutnya dengan ambiguitas, dapat terjadi tidak hanya terbatas antara kata saja, karena kita juga dapat menemukannya dalam morfem, frase, dan kalimat. Hal ini membuktikan bahwa makna homonimi sangatlah luas dan pantas untuk dikaji lebih lanjut lagi. Dalam penelitian ini, jenis homonimi yang dianalisis adalah homonimi kata dalam bahasa Indonesia dan bahasa Sunda.

Sedangkan mengenai Polisemi, ini lazim diartikan sebagai satuan bahasa (terutama kata, bisa juga frase) yang memiliki makna lebih dari satu (Chaer, 2002:101). Sebagai contoh, kata duga dalam bahasa Sunda memiliki makna (1) gula; (2) kira; (3) kuat; (4) tatakrama. Sementara Kirsten Malmkjær berpendapat bahwa polisemi hadir ketika sebuah kata yang ambigu mempunyai acuan yang berbedabeda dan dapat diterima kemiripannya dalam beberapa respek (1991:394).

Pengisi makna-makna dalam polisemi kemudian dikenal dengan komponen. Komponen-komponen makna ini berkembang dengan sendirinya. Sebagai contoh, misalnya frase kepala paku dan kepala jarum mempunyai komponen makna "berbentuk bulat" sebagai makna asalnya. Penelitian ini mencoba untuk melihat apakah ada bentuk polisemi yang sama di antara bahasa Indonesia dan bahasa Sunda berdasarkan teori-teori di atas.

\section{Metode}

Penelitian ini menggunakan metode deskriptif kualitatif untuk menjelaskan fenomena yang terjadi antara makna dan relasi makna dari bahasa Indonesia dan Bahasa Sunda. Populasi penelitian ini adalah penutur bahasa Sunda dalam komunitas masyarakat Sunda. Seperti telah dijelaskan di atas, data dari bahasa Indonesia dan bahasa Sunda diambil dari penutur bahasa Sunda untuk melihat apakah ada perbedaan makna di antara kosa kata homonimi dan polisemi. Selain dari penutur bahasa Sunda, data penelitian ini diambil dari cerita pendek berbahasa Sunda dan berbahasa Indonesia untuk melengkapi kekurangan data.

Sampel bahasa Indonesia dan bahasa Sunda adalah lima orang penutur bahasa Sunda yang berasal dan berbahasa ibu bahasa Sunda yang berprofesi sebagai pelajar, mahasiswa, dan wirausahawan. Sebagai pelengkap, penelitian ini mengambil data tambahan dari cerita pendek bahasa Sunda dan bahasa Indonesia untuk menambah data-data yang tidak terdapat dalam sampel wawancara.

Data penelitian ini dikumpulkan melalui sumber lisan dan tertulis dan dilengkapi dengan makna leksikal dan makna sesungguhnya yang tertera dalam kolom-kolom analisis data. Data lisan dari penelitian ini diambil dari wawancara dengan beberapa penutur bahasa Sunda dalam konteks percakapan seharihari. Sumber-sumber tertulis dari penelitian ini antara lain:

1. Untuk bahasa Indonesia diperoleh dari cerita pendek, kamus bahasa Indonesia, koran, majalah, dan kuisioner. 
2. Untuk bahasa Sunda diperoleh dari cerita pendek, kamus bahasa Sunda, buku pengajaran bahasa Sunda, dan kuisioner.

Data yang telah dikumpulkan kemudian dianalisis berdasarkan langkah-langkah teknik sebagai berikut:

1. Meneliti makna leksikal kosa kata bahasa Indonesia yang berbentuk sama dengan bahasa Sunda.

2. Meneliti makna leksikal kosa kata bahasa Sunda yang berbentuk sama dengan bahasa Indonesia.

3. Meneliti makna sebenarnya kosa kata bahasa Indonesia yang berbentuk sama dengan bahasa Sunda berdasarkan konteks kalimat.

4. Meneliti makna leksikal kosa kata bahasa Sunda yang berbentuk sama dengan bahasa Indonesia berdasarkan konteks kalimat.

Meneliti gejala sosial dan psikologis penggunaan kosa kata berbentuk sama dalam bahasa Indonesia dan bahasa Sunda.

\section{HASIL PENELITIAN DAN PEMBAHASAN}

Pengolahan data yang dilakukan dalam penelitian ini dibagi dalam tiga jenis analisis. Analisis pertama adalah pengelompokkan kosa kata dari bahasa Indonesia dan bahasa Sunda berdasarkan analisis leksikal yang terdiri atas: nama kosa kata, makna kamus Bahasa Indonesia, makna kamus bahasa Sunda, dan makna harfiah. Penggolongan ini dimaksudkan untuk mencari kosa kata homonimi dan polisemi beserta makna harfiah dalam bahasa Indonesia. Data-data yang dikumpulkan merupakan penggabungan dari data wawancara, kuisioner, dan cerita pendek berbahasa Indonesia dan berbahasa Sunda.

Analisis kedua adalah pengelompokkan kosa kata hiponimi dan polisemi berdasarkan makna sebenarnya dalam sebuah kalimat bahasa Indonesia dan bahasa Sunda. Penggelompokkan ini dimaksudkan untuk menyelaraskan makna leksikal dengan makna sebenarnya dari kosa kata hiponimi dan polisemi yang terdapat dalam bahasa Indonesia dan bahasa Sunda. Selain itu, analisis ini diharapkan dapat menemukan hal-hal baru mengenai makna dari kosa kata hiponimi dan polisemi bahasa Indonesia dan bahasa Sunda, dengan sistematika pembahasan sebagai berikut:

\section{Analisis Leksikal Kosa Kata} Hiponimi dan Polisemi Bahasa Indonesia dan Bahasa Sunda

Berdasarkan hasil pengolahan data kosa kata hiponimi dan polisemi di depan maka dapat diketahui penggolongan kosa kata sebagai berikut:

\section{Tabel 1. Makna Leksikal}

\begin{tabular}{|l|c|l|c|c|}
\hline No & $\begin{array}{c}\text { Nama } \\
\text { Kosa Kata }\end{array}$ & $\begin{array}{c}\text { Makna Leksikal Dalam Kamus } \\
\text { B.Ind }\end{array}$ & $\begin{array}{c}\text { Makna Leksikal } \\
\text { Dalam Kamus } \\
\text { B.Sunda }\end{array}$ & $\begin{array}{c}\text { Makna } \\
\text { Harfiah }\end{array}$ \\
\hline 1. & Adat & $\begin{array}{l}\text { Aturan yang lazim diturut atau } \\
\text { dilakukan sejak dahulu kala; cara } \\
\text { yang sudah menjadi kebiasaan; } \\
\text { wujud gagasan kebudayaan yang }\end{array}$ & Kabiasaan; tabeat & Kebiasaan \\
\hline
\end{tabular}




\begin{tabular}{|c|c|c|c|c|}
\hline No & $\begin{array}{l}\text { Nama } \\
\text { Kosa Kata }\end{array}$ & $\begin{array}{c}\text { Makna Leksikal Dalam Kamus } \\
\text { B.Ind }\end{array}$ & $\begin{array}{l}\text { Makna Leksikal } \\
\text { Dalam Kamus } \\
\text { B.Sunda }\end{array}$ & $\begin{array}{l}\text { Makna } \\
\text { Harfiah }\end{array}$ \\
\hline & & $\begin{array}{l}\text { terdiri atas nilai-nilai budaya, } \\
\text { norma, hukum, dan aturan yang } \\
\text { satu dengan yang lainnya } \\
\text { berkaitan menjadi suatu sistem; } \\
\text { cukai menurut aturan yang } \\
\text { berlaku. }\end{array}$ & & \\
\hline 2. & Akut & $\begin{array}{l}\text { Timbul secara mendadak dan } \\
\text { cepat memburuk; memerlukan } \\
\text { pemecahan segara; kurang dari } \\
90^{\circ}\end{array}$ & $\begin{array}{lr}\text { Ngunjal, } & \\
\text { nanggungan } & \text { pare } \\
\text { ti sawah } & \text { ka } \\
\text { lembur } & \end{array}$ & $\begin{array}{l}\text { Membaw } \\
\text { a padi } \\
\text { dari } \\
\text { sawah ke } \\
\text { kampong }\end{array}$ \\
\hline 3. & Ala & $\begin{array}{l}\text { Atas;pada;kepada;akan;tinggi; } \\
\text { secara; tanah yang tidak } \\
\text { dikerjakan lagi }\end{array}$ & $\begin{array}{l}\text { Newak, metik, } \\
\text { neangan; nenang, } \\
\text { manggil; } \\
\text { ngabogaan sipat } \\
\text { kawas bapana; } \\
\text { nincak waktu }\end{array}$ & $\begin{array}{l}\text { Tangkap, } \\
\text { petik; } \\
\text { cari; } \\
\text { panggil, } \\
\text { mempuny } \\
\text { ai sifat } \\
\text { seperti } \\
\text { ayahnya; } \\
\text { batas } \\
\text { waktu } \\
\text { akhir }\end{array}$ \\
\hline 4. & Amis & Anyir (berbau spt bau ikan) & $\begin{array}{l}\text { Rasa saperti rasa } \\
\text { gula }\end{array}$ & $\begin{array}{c}\text { Terasa } \\
\text { seperti } \\
\text { rasa gula }\end{array}$ \\
\hline 5. & Ari & $\begin{array}{l}\text { Kandang kuda; lapisan tipis; } \\
\text { ular; hari. }\end{array}$ & $\begin{array}{l}\text { Demi;lamun;wakt } \\
\text { u;mah }\end{array}$ & $\begin{array}{l}\text { Demi; } \\
\text { kalau; } \\
\text { waktu }\end{array}$ \\
\hline 6. & Asa & Semangat; sangka;sengaja & $\begin{array}{l}\text { Rasa, sangsi, era- } \\
\text { era. }\end{array}$ & $\begin{array}{l}\text { Rasa, } \\
\text { sangsi, } \\
\text { setengah- } \\
\text { setengah }\end{array}$ \\
\hline 7. & Bandang & $\begin{array}{l}\text { Besar dan deras (terutama untuk } \\
\text { air) }\end{array}$ & ngaboyong & $\begin{array}{c}\text { Membaw } \\
\text { a }\end{array}$ \\
\hline 8. & Bangun & $\begin{array}{l}\text { Bangkit; berdiri; jaga; belum } \\
\text { (tidak) tidur; siuman dari } \\
\text { pingsan; mulai sadar; mulai } \\
\text { menuai; mulai menjadi cair }\end{array}$ & Semu & Kayak \\
\hline 10. & Bincang & $\begin{array}{l}\text { Bercakap-cakap membicarakan } \\
\text { sesuatu; berunding. }\end{array}$ & $\begin{array}{l}\text { Dicangcang } \mathrm{ku} \\
\text { dua tambang } \mathrm{ka} \\
\text { kenca jeung } \mathrm{ka} \\
\text { katuhu ngarah } \\
\text { leuwih kuat. }\end{array}$ & $\begin{array}{c}\text { Dibelit } \\
\text { oleh dua } \\
\text { buah } \\
\text { tambang } \\
\text { dari kiri } \\
\text { ke kanan } \\
\text { supaya } \\
\text { lebih kuat }\end{array}$ \\
\hline 11. & Boga & $\begin{array}{l}\text { Makanan; minuman; hidangan; } \\
\text { santapan. }\end{array}$ & Gaduh & Punya \\
\hline 12. & Buah & Bagian tumbuhan yang berasal & Bagian tutuwuhan & Bagian \\
\hline
\end{tabular}




\begin{tabular}{|c|c|c|c|c|}
\hline No & $\begin{array}{l}\text { Nama } \\
\text { Kosa Kata }\end{array}$ & $\begin{array}{c}\text { Makna Leksikal Dalam Kamus } \\
\text { B.Ind }\end{array}$ & $\begin{array}{l}\text { Makna Leksikal } \\
\text { Dalam Kamus } \\
\text { B.Sunda }\end{array}$ & $\begin{array}{l}\text { Makna } \\
\text { Harfiah }\end{array}$ \\
\hline & & $\begin{array}{l}\text { dari bunga atau putik; kata } \\
\text { penggolong } \text { bermacam-macam } \\
\text { benda; pokok, bahan; hasil. }\end{array}$ & $\begin{array}{l}\text { anu asal tina } \\
\text { kembang; barang } \\
\text { nu siga buah; } \\
\text { hasil pagawean. }\end{array}$ & $\begin{array}{l}\text { tumbuhan } \\
\text { yang } \\
\text { bersasl } \\
\text { dari } \\
\text { kembang; } \\
\text { barang } \\
\text { yang } \\
\text { terlihat } \\
\text { seperti } \\
\text { buah; } \\
\text { hasil } \\
\text { pekerjaan }\end{array}$ \\
\hline 13. & Buat & $\begin{array}{l}\text { Kerjakan, lakukan; bikin; bagi; } \\
\text { untuk }\end{array}$ & $\begin{array}{l}\text { Buatan, jieunan; } \\
\text { dibuat, ngala pare. }\end{array}$ & $\begin{array}{l}\text { Buatan; } \\
\text { dibuat, } \\
\text { padi }\end{array}$ \\
\hline 14. & Burung & $\begin{array}{l}\text { Binatang berkaki dua, bersayap } \\
\text { dan berbulu, dan biasanya dapat } \\
\text { terbang; unggas; sebutan jenis } \\
\text { unggas. }\end{array}$ & teu jadi; gelo & $\begin{array}{c}\text { Tidak } \\
\text { jadi; gila }\end{array}$ \\
\hline 15. & Cita & $\begin{array}{l}\text { Rasa; perasaan hati; cipta; cita- } \\
\text { cita; cinta; ide; gagasan; kain } \\
\text { tenun dari kapas dsb yang } \\
\text { berwarna-warni. }\end{array}$ & $\begin{array}{l}\text { Encit, lawon ipis } \\
\text { bahan papakean }\end{array}$ & $\begin{array}{l}\text { Bahan } \\
\text { pakaian } \\
\text { perempua } \\
\text { n dari } \\
\text { tekstil }\end{array}$ \\
\hline 16. & Duka & Susah hati; sedih hati & Teu nyaho; susah. & $\begin{array}{l}\text { Tidak } \\
\text { tahu; } \\
\text { susah }\end{array}$ \\
\hline 17. & Ganas & $\begin{array}{l}\text { Galak dan suka menyerang; } \\
\text { mudah menular. }\end{array}$ & $\begin{array}{l}\text { Tutuwuhan anu } \\
\text { buahna ngacung } \\
\text { (ka luhur), siga } \\
\text { sisitan sarta } \\
\text { bujurna daunan } \\
\text { siga buntut }\end{array}$ & $\begin{array}{c}\text { Tumbuha } \\
\text { n yang } \\
\text { buahnya } \\
\text { menjulur } \\
\text { ke atas, } \\
\text { bersisik } \\
\text { serta } \\
\text { bagian } \\
\text { belakangn } \\
\text { ya seperti } \\
\text { ekor }\end{array}$ \\
\hline 18. & Gandeng & $\begin{array}{l}\text { Bersambung; berhubungan; } \\
\text { berbimbing (tangan) }\end{array}$ & $\begin{array}{l}\text { Aya atawa loba } \\
\text { sora }\end{array}$ & $\begin{array}{c}\text { Ada atau } \\
\text { banyak } \\
\text { suara }\end{array}$ \\
\hline 19. & Gigih & $\begin{array}{l}\text { Tetap teguh pendirian; ulet } \\
\text { (dalam usaha); gigil }\end{array}$ & $\begin{array}{l}\text { Sangu satengah } \\
\text { asak; mimiti gelo }\end{array}$ & $\begin{array}{l}\text { Nasi } \\
\text { setengah } \\
\text { jadi; } \\
\text { mulai gila }\end{array}$ \\
\hline 20. & Girang & Riang; gembira & $\begin{array}{l}\text { Tempat ngocorna } \\
\text { cai }\end{array}$ & $\begin{array}{l}\text { Tempat } \\
\text { keluarnya } \\
\text { air }\end{array}$ \\
\hline 21. & Gugah & Menggugah: & Hudang, nyaring, & Bangun \\
\hline
\end{tabular}




\begin{tabular}{|c|c|c|c|c|}
\hline No & $\begin{array}{l}\text { Nama } \\
\text { Kosa Kata }\end{array}$ & $\begin{array}{c}\text { Makna Leksikal Dalam Kamus } \\
\text { B.Ind }\end{array}$ & $\begin{array}{l}\text { Makna Leksikal } \\
\text { Dalam Kamus } \\
\text { B.Sunda }\end{array}$ & $\begin{array}{l}\text { Makna } \\
\text { Harfiah }\end{array}$ \\
\hline & & membangkitkan; menyentuh hati & lilir & \\
\hline 22. & Jarah & Hasil rampasan dalam perang. & $\begin{array}{lr}\begin{array}{l}\text { Hirup } \\
\text { (sasatoan); }\end{array} & \text { bebas } \\
\text { robahan } & \text { tina } \\
\text { zarrah } & (\mathrm{Ar}): \\
\text { bentang } & \text { jarah. } \\
\text { planit; robahan } & \\
\text { tina ziarah. } & \end{array}$ & $\begin{array}{l}\text { Hidup } \\
\text { bebas; } \\
\text { ziarah }\end{array}$ \\
\hline 23. & Kalah & $\begin{array}{l}\text { Tidak menang atau dalam } \\
\text { keadaan tidak menang (di } \\
\text { perkelahian, } \\
\text { pertandingan, pemilihan, dsb); } \\
\text { dapat diungguli lawan. }\end{array}$ & $\begin{array}{l}\text { Anggur; } \\
\text { bawaning; } \\
\text { kalahka , ngan } \\
\text { ukur..... }\end{array}$ & Malah \\
\hline 24. & Kami & $\begin{array}{l}\text { Yang berbicara bersama dengan } \\
\text { orang lain; yang berbicara } \\
\text { (digunakan oleh orang besar). }\end{array}$ & $\begin{array}{l}\text { Jalma kahiji nu } \\
\text { bareto sok dipake } \\
\text { ka sahandapeun } \\
\text { pisan }\end{array}$ & $\begin{array}{c}\text { Orang } \\
\text { pertama } \\
\text { yang suka } \\
\text { dipakai } \\
\text { oleh } \\
\text { orang } \\
\text { yang } \\
\text { berbicara } \\
\text { kepada } \\
\text { yang } \\
\text { seusia di } \\
\text { bawahnya }\end{array}$ \\
\hline 25. & Labuh & $\begin{array}{l}\text { Dalam keadaan turun atau } \\
\text { tergelantung ke bawah seperti } \\
\text { kelambu, tali, jangkar, tirai, atau } \\
\text { layer panggung }\end{array}$ & $\begin{array}{l}\text { Ngagolepak kana } \\
\text { taneuh lantaran } \\
\text { tisoledat, } \\
\text { kadupak, } \\
\text { jste;ragrag. }\end{array}$ & $\begin{array}{l}\text { Terjatuh } \\
\text { ke tanah } \\
\text { karena } \\
\text { terpeleset }\end{array}$ \\
\hline 26. & Lebah & $\begin{array}{l}\text { Serangga berbulu, bersayap } \\
\text { empat dan hidup dari madu } \\
\text { kembang; bentuk dagu yang } \\
\text { indah; nama ukiran pada jubung- } \\
\text { jubung perahu; corak atau } \\
\text { gambar pada kain. }\end{array}$ & $\begin{array}{l}\text { Deukeut; teu jauh } \\
\text { ti..... }\end{array}$ & $\begin{array}{c}\text { Dekat; } \\
\text { tidak jauh } \\
\text { dari...... } \\
\quad \ldots\end{array}$ \\
\hline 27. & Lenyap & $\begin{array}{l}\text { Tidak kelihatan lagi; tidak jaga; } \\
\text { nyenyak }\end{array}$ & $\begin{array}{lr}\text { Kana reup } & \text { sare } \\
\text { atawa } & \text { kana } \\
\text { nyeblak } & \text { hate; } \\
\text { ngagebeg; } & \\
\text { kembang jambu }\end{array}$ & $\begin{array}{l}\text { Baru tidur } \\
\text { atau } \\
\text { berdebarn } \\
\text { ya hati; } \\
\text { kembang } \\
\text { buah } \\
\text { jambu }\end{array}$ \\
\hline 28. & Lembur & $\begin{array}{l}\text { Pekerjaan dinas yang dilakukan } \\
\text { di luar jam }\end{array}$ & Kampung & Kampung \\
\hline 29. & Lembut & $\begin{array}{l}\text { Lunak dan halus; tidak keras; } \\
\text { baik hati; kecil sekali }\end{array}$ & $\begin{array}{l}\text { Lembet, leutik; } \\
\text { lemes }\end{array}$ & $\begin{array}{l}\text { Kecil; } \\
\text { lembut }\end{array}$ \\
\hline
\end{tabular}




\begin{tabular}{|c|c|c|c|c|}
\hline No & $\begin{array}{l}\text { Nama } \\
\text { Kosa Kata }\end{array}$ & $\begin{array}{c}\text { Makna Leksikal Dalam Kamus } \\
\text { B.Ind }\end{array}$ & $\begin{array}{c}\text { Makna Leksikal } \\
\text { Dalam Kamus } \\
\text { B.Sunda }\end{array}$ & $\begin{array}{l}\text { Makna } \\
\text { Harfiah }\end{array}$ \\
\hline 30. & Lini & Garis tengah; garis pertengahan & $\begin{array}{l}\text { Lindu; oyagna } \\
\text { bumi ku lantaran } \\
\text { aya gunung bitu } \\
\text { atawa aya } \\
\text { parobahan anu } \\
\text { hebat di jero bumi }\end{array}$ & $\begin{array}{c}\text { Bergetarn } \\
\text { ya bumi } \\
\text { karena } \\
\text { ada } \\
\text { letusan } \\
\text { gunung } \\
\text { atau ada } \\
\text { perubahan } \\
\text { yang } \\
\text { dahsyat di } \\
\text { dalam } \\
\text { bumi }\end{array}$ \\
\hline 31. & Luas & $\begin{array}{l}\text { Lapang; lebar; umum; merata; } \\
\text { ukuran panjang lebarnya bidang; } \\
\text { banyak dan beragam; dapat } \\
\text { melihat bebas dan lepas; besar } \\
\text { atau banyak. }\end{array}$ & $\begin{array}{l}\text { Tega; gilig hate, } \\
\text { moal nyoreang ka } \\
\text { tukang }\end{array}$ & $\begin{array}{l}\text { Tega; } \\
\text { tidak akan } \\
\text { berbalik } \\
\text { ke } \\
\text { belekang }\end{array}$ \\
\hline 32. & Mangga & $\begin{array}{l}\text { Pohon yang berbatang tegak, } \\
\text { bunganya berbentuk malai, } \\
\text { buahnya bulat panjang atau bulat } \\
\text { pendek, warna, daging, buah dan } \\
\text { rasanya bervariasi. }\end{array}$ & $\begin{array}{l}\text { Heug atawa daek; } \\
\text { ngajak atwa } \\
\text { ngajurung. }\end{array}$ & $\begin{array}{l}\text { Baik atau } \\
\text { mau; } \\
\text { mengajak } \\
\text { atau } \\
\text { menganta } \\
\text { r }\end{array}$ \\
\hline 33. & Mentas & $\begin{array}{l}\text { Keluar; lepas dari tanggungan } \\
\text { keluarga. }\end{array}$ & Sanggaeus & Setelah \\
\hline 34. & Pasir & $\begin{array}{l}\text { Butir-butir batu yang halus; } \\
\text { lapisan tanah atau timbunan } \\
\text { kersik halus; berbutir-butir } \\
\text { sebagai pasir; laut. }\end{array}$ & Gunung leutik & $\begin{array}{c}\text { Gunung } \\
\text { kecil }\end{array}$ \\
\hline 35. & Pernah & Sudah menjalani; ada kalanya. & $\begin{array}{l}\text { Pantes, lebah, } \\
\text { tempat, pancakaki }\end{array}$ & $\begin{array}{l}\text { Pantas; } \\
\text { tempat }\end{array}$ \\
\hline 36. & Rupa & $\begin{array}{l}\text { Keadaan tampak di luar; roman } \\
\text { muka; wujud; bangun; macam; } \\
\text { jenis }\end{array}$ & $\begin{array}{l}\text { Warna; bangun; } \\
\text { rupana, kawasna. }\end{array}$ & $\begin{array}{l}\text { Warna; } \\
\text { seperti; } \\
\text { rupanya; } \\
\text { sepertinya }\end{array}$ \\
\hline 37. & Suku & $\begin{array}{l}\text { Kaki; sebagian dari empat; } \\
\text { tengahan rupiah; uang emas yang } \\
\text { dipakai juga sebagai ukuran } \\
\text { berat emas; bagian; bilangan } \\
\text { yang menjadi bagian dari } \\
\text { perbandingan atau jajaran } \\
\text { bilangan; golongan orang-orang } \\
\text { yang seturunan; golongan orang } \\
\text { dari sebagian keturunan; } \\
\text { klasifikasi di biologi sesudah } \\
\text { bangsa sebelum marga }\end{array}$ & $\begin{array}{lr}\begin{array}{l}\text { Anggahota } \\
\text { (jelema }\end{array} & \text { adawa } \\
\text { sato) } & \text { paranti } \\
\text { nangtung; } & \text { duit } \\
\text { baheula } & \end{array}$ & $\begin{array}{l}\text { Anggota } \\
\text { badan } \\
\text { (manusia } \\
\text { atau } \\
\text { hewan) } \\
\text { untuk } \\
\text { berdiri; } \\
\text { uang } \\
\text { jaman } \\
\text { dahulu }\end{array}$ \\
\hline 38. & Sulit & $\begin{array}{l}\text { Sukar sekali;susah; susah dicari; } \\
\text { dirahasiakan; gelap; di keadaan }\end{array}$ & Teu kaopan & $\begin{array}{l}\text { Mudah } \\
\text { tersinggu }\end{array}$ \\
\hline
\end{tabular}




\begin{tabular}{|c|c|c|c|c|}
\hline No & $\begin{array}{l}\text { Nama } \\
\text { Kosa Kata }\end{array}$ & $\begin{array}{c}\text { Makna Leksikal Dalam Kamus } \\
\text { B.Ind }\end{array}$ & $\begin{array}{l}\text { Makna Leksikal } \\
\text { Dalam Kamus } \\
\text { B.Sunda }\end{array}$ & $\begin{array}{l}\text { Makna } \\
\text { Harfiah }\end{array}$ \\
\hline & & yang sukar. & & ng \\
\hline 39. & Tas & $\begin{array}{l}\text { Kemasan atau wadah berbentuk } \\
\text { persegi dsb biasanya bertali; } \\
\text { segera; pohon yang menurut } \\
\text { sebagian orang sebagai } \\
\text { penangkal harimau, buahnya } \\
\text { dapat dimakan }\end{array}$ & Sanggeus; wadah. & $\begin{array}{l}\text { Setelah; } \\
\text { tempat } \\
\text { sesuatu }\end{array}$ \\
\hline 40. & Teh & $\begin{array}{l}\text { Pohon kecil, tumbuh di alam } \\
\text { bebas, daunnya berbentuk jorong } \\
\text { atau bulat telur, pucuknya } \\
\text { dilayutkan dan dikeringkan } \\
\text { untuk dibuat minuman. }\end{array}$ & Meh sarua & $\begin{array}{l}\text { Supaya } \\
\text { sama }\end{array}$ \\
\hline 41. & Tulus & $\begin{array}{l}\text { Sungguh dan bersih hati; jujur; } \\
\text { tidak pura-pura; tidak serong; } \\
\text { tulus hati; tulus ikhlas }\end{array}$ & Cios, jadi. & Jadi \\
\hline
\end{tabular}

Hal-hal yang dianggap penting pada data-data di atas antara lain:

1. Kosa kata hiponimi bahasa Indonesia dan bahasa Sunda secara leksikal banyak terdapat dalam konteks asal kata.

2. Kosa kata polisemi bahasa Indonesia lebih banyak dibandingkan dengan bahasa Sunda karena faktor kedudukan bahasa Indonesia sebagai bahasa nasional dengan cakupan penutur yang lebih banyak dari bahasa Sunda.

\section{Kosa Kata Hiponimi dan Polisemi Bahasa Indonesia dan Bahasa Sunda}

Berdasarkan hasil olahan data kosa kata hiponimi dan polisemi dalam bahasa Indonesia dan bahasa Sunda dapat diketahui hal-hal yang dianggap penting dalam penelitian ini (untuk lebih jelasnya dapat dilihat pada Lampiran). Hal-hal tersebut antara lain:

1. Bahwa dalam bahasa Indonesia dan bahasa Sunda banyak terdapat kosa kata hiponimi dan polisemi.
2. Berdasarkan data, bahasa Indonesia memiliki sebuah polisemi, yakni:

a. Toko buah milik ayahku bernama toko "BARDAN". (DHP:10)

b. Pasangan ini harus ikhlas melepaskan buah hatinya menghadap Allah

Rabbul 'alamin.

c. Buah dada wanita itu kelihatan sangat besar.

d. Buah gedong nu aya di buruan keur meuhpeuy buahna. (DHP:10)

Terhadap kalimat d di atas, dapat dianalisis bahwa:

Mangga gedong yang ada di halaman lagi matang buahnya.

'Mangga gedong yang ada di halaman buahnya sedang matang.' Makna kata buah dalam data di atas berpolisemi menjadi tiga buah:

'bagian tumbuhan yang berasal dari bunga atau putik (10.a1)'; 'anak' (b); dan 'payudara' (c); sedangkan hiponim dari kata buah dalam bahasa Sunda bermakna 'buah mangga' dan 'buah'. 
3. Berdasarkan data, bahasa Sunda memiliki empat buah polisemi, yakni:

a. i. Bau amis darah itu membuat kepalaku jadi pusing.

ii. Neng Santi katelah di kampungna istri anu amis budi.

Neng Santi terkenal di kampungnya perempuan yang manis budi.

'Neng Santi di kampungnya terkenal karena baik budinya.'

iii. Si Dodon mah budakna amis daging.

Si Dodon anaknya manis daging.

'Si Dodon itu anaknya gampang terkena penyakit kulit.'

iv. Kamari Dodon mere gedang meni amis pisan.

Kemarin Dodon memberikan papaya sangat manis.

'Kemarin Dodon memberikanku papaya yang sangat manis.'

Makna kata amis dalam data (i) adalah 'bau anyir'. Akan tetapi dalam bahasa Sunda berpolisemi menjadi tiga buah makna. Dua buah makna dibentuk dari frase kata benda, yaitu: 'baik' pada frase amis budi dan 'gampang terkena penyakit kulit', dan pada frase amis daging. Makna lain dari kata amis dalam bahasa Sunda adalah 'manis' (iv). Biasanya kata amis ini diserupakan pada jenis buah-buahan.

i. Setiap pagi burung kutilang itu bernyanyi di pohon randu.

ii. Dasar jelema burung, kamamana teu dibaju. Dasar orang gila, kemana-mana tidak memakai pakaian.'Dasar orang gila, kemanamana tidak memakai pakaian.'

iii.Lamun boga mobil mah moal burung teu payu urang teh. Kalau punya mobil tidak jadi tidak laku saya.

'Kalau punya mobil, saya tidak akan sendiri.'
Makna kata burung dalam data b.i adalah 'unggas'. Akan tetapi dalam bahasa Sunda berubah dan berpolisemi menjadi dua buah makna. Dua buah makna itu adalah 'gila' (b.ii) dan 'tidak jadi' (b.iii).

c. i.Para pendemo sedang menjarah toko.

ii.Ibu nuju jarah ka makam nini. Ibu sedang ziarah ke makam nenek. 'Ibu sedang menziarahi makam nenek.'

iii. Di leuwueng loba munding jarah. Di hutan banyak kerbau yang hidup bebas. Di hutan banyak kerbau liar'

Makna kata jarah dalam c.i adalah 'merampas', sedangkan dalam bahasa Sunda berpolisemi menjadi dua buah makna:'ziarah' (c.ii) dan

'hidup bebas atau liar (c.iii).

d. i Pemain lini depan itu banyak digandrungi wanita.

ii.Basa aya lini, ampir kabeh imah di ieu kampung rata jeung taneuh. Ketika ada gempa, hampir semua rumah di ini kampung rata dengan tanah. 'Ketika ada gempa, hampir semua rumah di kampung ini rata dengan tanah.'

iii.Lamun papanggih jeung awewe urang mah sok lilinieun. Kalau bertemu dengan wanita saya suka bergetar.'Kalau bertemu wanita, saya suka gemetaran.'

Makna kata lini dalam d.i adalah 'garis tengah', sedangkan dalam bahasa Sunda kata lini berpolisemi menjadi dua buah makna: 'gempa'

(ii) dan 'gemetaran' (iii).

4. Kosa kata hiponimi dalam bahasa Indonesia dan bahasa Sunda sebagian besar memiliki makna yang jauh berbeda, misalnya:

a. Dengan girang aku terima hadiah dari ayahku. (DHP:14) 
b.Ari cai ngocorna ti girang ka hilir. (DHP:14)

Air mengalir dari atas ke bawah.

'Air mengalir dari atas ke bawah.'

Makna kata girang dalam data a adalah 'senang', sedangkan dalam data $b$ bermakna 'atas (tempat mengalir air)'.

5. Penutur bahasa Sunda sudah biasa mengenal kosa kata bahasa Sunda yang berhiponimi dengan bahasa Indonesia. Ini terbukti dengan hasil data yang menunjukkan kalimat-kalimat bahasa Indonesia yang terstruktur dengan rapi.

6. Bahwa terdapat unsur sosiologi maupun psikologis yang terjadi pada penutur ketika mengucapkan kosa kata yang berhiponim. Hal ini terbukti ketika penutur memberikan contoh kalimat: $\underline{\text { Buah dada wanita itu }}$ kelihatan sangat besar. Dalam konteks kalimat seperti ini, maka dapat ditarik kesimpulan bahwa penutur tidak canggung ketika mengucapkan kata 'buah dada' karena kata buah sendiri dalam bahasa Sunda bermakna mangga.

7. Adanya relasi makna antara kosa kata bahasa Indonesia dan bahasa Sunda yang ditunjukkan dengan banyaknya sumber data kosa kata berhiponimi dan polisemi.

\section{SIMPULAN}

Berdasarkan hasil penelitian mengenai kosa kata hiponimi dan polisemi dalam bahasa Indonesia dan bahasa Sunda, maka dapat diambil kesimpulan sebagai berikut.
Secara leksikal, kosa kata polisemi bahasa Indonesia lebih banyak dibandingkan dengan bahasa Sunda. Hal ini disebabkan karena faktor kedudukan bahasa Indonesia sebagai bahasa nasional dengan cakupan penutur yang lebih banyak dari bahasa Sunda. Berdasarkan data, bahasa Indonesia memiliki sebuah polisemi, yaitu pada kata buah yang berpolisemi menjadi: buah; buah hati; dan buah dada. Sedangkan bahasa Sunda memiliki empat buah polisemi, yakni: (1) kata amis yang bermakna baik budinya, amis daging yang bermakna mudah terkena penyakit kulit, dan amis yang berarti manis.

Penutur bahasa Sunda sudah biasa mengenal kosa kata bahasa Sunda yang berhiponimi dengan bahasa Indonesia. Ini terbukti dengan hasil data yang menunjukkan kalimat-kalimat bahasa Indonesia yang terstruktur dengan rapi.

1. Bahwa terdapat unsur sosial maupun psikologis yang terjadi pada penutur ketika mengucapkan kosa kata yang berhiponim. Hal ini terbukti ketika penutur memberikan contoh kalimat: $\underline{\text { Buah }}$ dada wanita itu kelihatan sangat besar. Dalam konteks kalimat seperti ini, maka dapat ditarik kesimpulan bahwa penutur tidak canggung ketika mengucapkan kata 'buah dada' karena kata buah sendiri dalam bahasa Sunda bermakna mangga.

2. Adanya relasi makna antara kosa kata bahasa Indonesia dan bahasa Sunda yang ditunjukkan dengan banyaknya sumber data kosa kata berhiponimi dan polisemi. 


\section{REFERENSI}

Alwasilah, Chaedar. 2002. Pokoknya Kualitatif. Bandung : PT. Dunia Pustaka Jaya.

Arikunto, Suharsimi. 2006. Prosedur Penelitian Suatu Pendekatan Praktik. Jakarta: Rineka Cipta.

Cresswell, John. W. 1994. Research Design, Qualitative \& Quantitative Approach. United Kingdom. SAGE Publications, inc.

Crystal, David. 1985. A dictionary of Linguistics and Phonetics Oxford. New York.

Hornby. 1987. Oxford Advanced Learner's Dictionary of Current English. Oxford University Press.

Katz, J.J. 1972. Semantics Theory. New York: Cambridge University press.

Leech, G. 1974. Semantics: the study of meaning. Second Edition. Harmondsworth: Penguin Books.

Lyons, John. 1977. Semantics. London: Cambridge University Press.

Maxwell, Joseph A. 1996. Qualitative Research Design, An Interactive Approarch. London. Sage Publications.

Oxford Dictionaries, 2014. Definition Politic and Terms in English. 7 Mei 2014. <http://www.oxforddictionari es.com/definition/english/poli tic?q=politic >

Palmer, F.R. 1976. Semantics A New Outline. London: Cambridge University Press.

Parera, J.D. 1991. Teori Semantik. Jakarta: Penerbit Erlangga.

Roshco, B. 1975. 'Newsmaking', reprinted in H.Tumber (1999) News: a reader, Oxford: Oxford University Press.

Saeed, Jhon I. 1997. Semantics. Massachusetts: Blackwell. Publisher.

Syamsul M. Romli, Asep. 2009 Jurnalistik Praktis Untuk Pemula. Bandung: PT. Remaja Rosdakarya.

Yule, George. 2010. The Study of Language. United Kingdom: C.U.P. 